\title{
PENGEMBANGAN TEKNIK DAN INSTRUMEN ASESMEN ASPEK PENGETAHUAN BERBASIS TEKNOLOGI
}

\author{
Hambali Alman Nasution ${ }^{1}$, Fikri Alwi Nasution ${ }^{2}$ \\ ${ }^{1}$ Universitas Islam Negeri Sunan Kalijaga \\ ${ }^{2}$ Universitas Islam Negeri Sumatera Utara \\ Email:hambalialmannasution@gmail.com
}

\begin{abstract}
ABSTRAK
Tujuan penelitian ini adalah untuk mengetahui pengembangan teknik dan instrumen asesmen aspek pengetahuan berbasis teknologi. Asesmen (penilaian) berbasi teknolgi ditinjau dari segi pendidikan merupakan proses penialaian yang dilakukan dengan melibatkan media seperti computer, LCD, Handphone, dan sejenisnya, guna mengoptimalkan pembelajaran yang lebih efesien dan menarik. Oleh karena itu perkembangan kemajuan teknologi dapat digunakan dalam pengembangan teknik dan assesmen aspek pengetahuan berbasis teknologi. Penelitian ini menggunakan jenis penelitian kepustakaan (Liberary Reseach). Hasil dalam penelitian ini dijelaskan bahwa dalam proses asesmen terdapat dua teknik yang efesien untuk diaktualisasikan yakni teknik tes dan non tes dengan instrumen pilihan ganda, lisan, dan penugasan atau pekerjaan rumah. Selain dari pada itu, terdapat pula berbagai aplikasi yang dapat digunakan guru dalam proses asesemen diantaranya exam view, bank soal rumah belajar, e-fortofolio, digital rubric, dan alternatif asesmen digital.
\end{abstract}

Kata kunci: Pengembangan Teknik, Asesmen, Pengetahuan, Teknologi.

\begin{abstract}
The purpose of this study is to investigate the development of techniques and instruments for assessing aspects of technology-based knowledge. Technology-based assessment (assessment) in terms of education is an assessment process that is carried out by involving media such as computers, LCDs, mobile phones, and the like, in order to optimize learning that is more efficient and interesting. Therefore the development of technological advances can be used in the development of techniques and assessment of aspects of technology-based knowledge. This study uses a type of library research (Liberary Research). The results in this study explained that in the assessment process there are two efficient techniques to be actualized, namely test and non-test techniques with multiple choice instruments, oral, and assignments or homework. Apart from that, there are also various applications that can be used by teachers in the assessment process including exam view, home learning bank, e-portfolio, digital rubric, and alternative digital assesments.
\end{abstract}

Keywords: Engineering Develoment, Asesment, Knowledge, Technology

\section{PENDAHULUAN}

Pendidikan merupakan peran penting untuk menciptakan masyarakat yang cerdas, baik itu dari segi intlektual, emosionalnya dan spritualnya. Dalam pelaksanaanya, pendidikan harus disesuaikan dengan tujuan pendidikan nasional yang sudah termktub di dalam UU RI No 20 Tahun 2003 yaitu sistem pendidikan nasional pada Bab II pasal 3, tentang membentuk watak serta mengembangkan 
kemampuan dan peradaban bangsa bermartabat sebagai rangka untuk mencerdaskan kehidupan bangsa. ${ }^{1}$ Pemerintah telah melakukan penyempurnaan kurikulum untuk meningkatkan kualitas pendidikan nasional. Dengan melakukan beberapa perubahan kurikulum hinga menjadi kurikulum 2013. Sesuai dengan tuntutan kurikulum, dalam proses belajar atau pendidikan harus melakukan perhatian terhadap assesmen. ${ }^{2}$ Hal yang pokok yang harus diperhatikan juga dalam pendidikan adalah perencanaan, pelaksanaan dan evaluasi. ${ }^{3}$ Pendidikan dewasa ini, mempunyai andil yang besar dalam mewujudkan masyarakat yang cerdas, baik dalam segi emosional, intelektual maupun spiritual. ${ }^{4}$

Begitupula diharapkan bahwa pelakasanaan pendidikan mampu sejalan dengan tujuan pendidikan itu sendiri. Perwujudan tujuan pendidikan tersebut, terdapat langkah yang digunakan oleh pemerintah adalah penyempurnaan Kuruikulum Tingkat Satun Pendidikan (KTSP) menjadi Kurikulum 2013 (K.13). Dengan adanya penyempurnaan kurikulum ini diharapkan mampu meningkatkan kemampuan peserta didik secara universal, baik dari aspek sikap, sosial, keterampilan, spiritual maupun aspek pengetahuannya.

Pemanfaatan teknologi, kini menjadi jalan alternatif yang populer digunakan oleh pihak sekolah dalam meningkatkan mutu pendidikan. Terlepas dari hal tersebut, bantuan teknologi juga sangat berperan penting bagi guru dalam mengoptimalkan pembelajaran. tidak bisa dipungkiri bahwa pembelajaran yang dibarengi dengan teknologi mampu meningkatkan kreativitas peserta didik serta mampu membantu guru dalam mengolah pembelajaran semenarik mungkin. Salah satu bagian pemanfaatan teknolgi yang sering digunakan guru yaitu pada proses assesmen (Penilaian). ${ }^{5}$

Asesmen adalah bagian dari komponen kurikulum yaitu sebagai perencanaan dalam melakukan kegiatan. Dalam pendidikan, asesmen bukan hanya digunakan sebagai alat untuk mencari informasi untuk mengetahui pencapaian belajar, tetapi juga bisa terhubung dengan komponen-komponen lainnya. Lewat

${ }^{1}$ Tim Penyusun, UU RI No 20 Tahun 2003 Tentang Sistem Pendidikan Nasional Bab II Pasal 3. Tujuan Pendidikan Nasional (Jakarta, 2003).

2 Dian Agustin, Nina Kadaritna, dan Lisa Tania, "PENGEMBANGAN INSTRUMEN ASESMEN PENGETAHUAN PADA MATERI TEORI ATOM BOHR DAN MEKANIKA KUANTUM," Jurnal Pendidikan Dan Pembelajaran Kimia 4, no. 1 (3 Juni 2015): 209-21.

3 Tatang Hidayat dan Abas Asyafah, "KONSEP DASAR EVALUASI DAN IMPLIKASINYA DALAM EVALUASI PEMBELAJARAN PENDIDIKAN AGAMA ISLAM DI SEKOLAH," Al-Tadzkiyyah: Jurnal Pendidikan Islam 10, no. 1 (29 Mei 2019): 159-81, https://doi.org/10.24042/atjpi.v10i1.3729.

${ }^{4}$ Dian Agustin, 'Pengembangan Isntrumen Asesmen Pengetahuan Pada Materi Teori Atom Bohr Dan Mekanika Kuantum', Jurnal Pendidikan Dan Pembelajaran Kimia, 4.1 (2015), 209.

${ }^{5}$ Endang Sri Maruti and Naniek Kusumawati, 'Proses Pengembangan Asesmen Alternatif Berupa Penilaian Produk Pada Mata Kuliah Pembelajaran Bahasa Jawa Di Sd', Jurnal Pendidikan Dasar Perkhasa: Jurnal Penelitian Pendidikan 2018 <https://doi.org/10.31932/jpdp.v4i2.175>. 
evaluasi, komponen lain juga bisa dikaji arena evaluasi melibatkan komponen lainnya. ${ }^{6}$

Asesmen merupakan kegiatan penting dalam proses pembelajaran, dengan digunakanya proses ini dapat berhasil apabila direncanakan dengan baik dengan tahap perancanaan, pelaksanaan, asesmen atau penilaian. Untuk menilai proses pembelajaran diperlukan sebuah asesmen, oleh karena itu pengembangan teknik dalam asesmen perlu dilakukan. Dengan asesmen kita juga dapat mengetahui sejauh mana kefektifan cara yang digunakan sebagai keberhasilan materi yang disampaikan, maka dengan asesmen bisa dilakukan untuk memperbaiki proses pembelajaran. ${ }^{7} \mathrm{Hal}$ ini juga sesuai dan berpengaruh dengan pengembangan teknik dan instrument assesmen aspek pengetahuan berbasis teknologi. Jika ditinjau dari segi teknologi, adalah suatu hal yang merupakan untuk mempermudah suatu pekerjaan. Secara istilah, teknologi bukanlah hal yang baru lagi dalam pendidikan, karena teknologi merupakan alat yang dapat mengelola, memperoses serta menyebarkan informasi melalui kombinasi beberapa perangkat teknologi.

Dalam pengumpulan informasi perkembangan belajar siswa pada berbagai aspek untuk mengukur ketercapaian indikator pembelajaran dilakukan dengan assesmen. ${ }^{8}$ Assesmen adalah upaya untuk mengolah dan mengumpulkan informasi atau data yang reliabel dan shahih (valid) guna melakukan pertimbangan untuk pengambilan kebijakan dalam suatu program pendidikan. ${ }^{9}$ Asesmen juga bisa dimaknai sebagai proses untuk mendapatkan informasi dalam bentuk apapun yang dapat digunakan sebagai dasar pengambilan keputusan baik bersangkutan dengan kurikulum ataupun proses pembelajaran.

\section{METODE PENELITIAN}

Metode analisis yang digunakan dalam pada penelitian ini yaitu analisis deskriptif kualitatif. Analisisis deskriptif kualitatif merupakan cara analisis yang cenderung menggunakan kata-kata untuk menggambarkan dan menjelaskan fenomena atau data yang diperoleh.

Adapun jenis penelitian yang digunakan adalah penelitian kepustakaan (library reserch) penelitian yang digunakan untuk memecahkan suatu problem

\footnotetext{
${ }^{6}$ sudaryono, Dasar-Dasar Evaluasi Pembelajaran (Yogyakarta: graha ilmu, 2012). Hal. $35-36$

7 Komang Setemen, Luh Joni Erawati, dan I. Ketut Purnamawan, "MODEL PEER ASSESSMENT BERBASIS TEKNOLOGI INFORMASI DAN KOMUNIKASI," Jurnal Pendidikan Teknologi Dan Kejuruan 16, no. 1 (30 Januari 2019): 55-64, https://doi.org/10.23887/jptk-undiksha.v16i1.16619.

${ }^{8}$ Widi Puji Astuti, Andreas Priyono Budi Prasetyo, dan Enni Suwarsi Rahayu, "PENGEMBANGAN INSTRUMEN ASESMEN AUTENTIK BERBASIS LITERASI SAINS PADA MATERI SISTEM EKSKRESI," Lembaran Ilmu Kependidikan 41, no. 1 (2012), https://journal.unnes.ac.id/nju/index.php/LIK/article/view/2228.

${ }^{9}$ Ridwan Abdullah Sani, "Pembelajaran Saintifik untuk Implementasi Kurikulum 2013 (Jakarta: Bumi Aksara, 2014).
} 
yang bersifat konseptual teoritis, baik tentang tokoh pendidikan ataupun konsep pendidikan tertentu seperti tujuan, metode, teknik dan lingkungan pendidikan. ${ }^{10}$ Secara sederhana penelitian kepustakaan adalah jenis penelitian yang berusaha mengimpundata dari berbagai literatur dan menjadikan sebagai objek utama analisisnya. ${ }^{11}$ Dalam penelitian ini, penulis ingin meneliti dan menganalisis pengembangan teknik dan instrumen asesmen aspek pengetahuan berbasis teknologi.

Penulis mengumpukan data dengan cara dokumentasi. Dokumentasi atau studi dokumenter (documentary study) merupakan suatu teknik pengumpulan data dengan menghimpun dan menganalisis dokumen-dokumen, baik dokumen tertlis, gambar maupun elektronik. ${ }^{12}$ Nuku-buku, jurnal-jurnal dan sumber internet yang digunakan dalam penelitian ini bertujuan untuk memperoleh data mengenai pengembangan teknik dan instrumen asesmen aspek pengetahuan berbasis teknologi.

\section{HASIL DAN PEMBAHASAN}

Aspek kognitif atau pengetahuan adalah salah satu objek dalam evaluasi pendidikan. Aspek kognitif adalah ranah yang menggunakan kegiatan kerja otak. Ranah ini meliputi, berfikir, menghafal, memahami, mengaplikasikan, menganalisis, menyintesisi dan mengevaluasi. ${ }^{13}$ Dalam refrensi lain juga disebutkan bahwa istilah kognitif bukan hanya sekedar kemampuan pemahaman, akan tetapi suatu prosesmental dalam merespon soal-soal tes. ${ }^{14}$ seperti tabel berikut hal yang harus diketahui dalam penegmbangan teknik intrumen asesmen aspek pengetahuan.

Dalam dimensi pengetahuan sendiri ada empat komponen diantaranya (1) pengetahuan faktual :unsur-unsur dasar aneka disiplin ilmu (2) pengetahuan konseptual : pengetahuan dengan menghubungkan unsur-unsur dasar kepada hal yang lebih kompleks. (3) pengetahuan prosedural : pengetahuan yang akan membantu siswa untuk lebih secara spesifik dalam mempelajari disiplin ilmu. (4) pengetahuan metakognitif : pengetahuan tentang aneka berpikir secara khas. Dimensi ranah kognitif atau dimensi proses kognitif adalah tingkatan pada kemampuan siswa, mulai dari mengingat, lalumemahami, kemudian

${ }^{10}$ Suwardi dkk, Panduan Penulisan Skripsi (Yogyakarta: FITK UIN Sunan Kalijaga, 2012) hal 20 .

${ }^{11}$ Suwardi dkk,

12 Nana Syaodih Sukmadhinata, Metode Penelitian Pendidikan (Bandung: PT. Remaja Rosdakarya, 2012). 55

${ }^{13}$ Sukiman, Pengembangan Sistem Evaluasi”, (Yogyakarta: Insan Madani, 2012). Hal.

${ }^{14}$ Raka Joni, Pengukuran dan Penilaian Pendidikan (Malang: Yayasan Pusat Pengkajian Dan Pengembangan Masyarakat, 1984). Hal. 63 
mengaplikasikan, lanjut menganalisis, setelahnya mengevaluasi dan yang terakhir mencipta. ${ }^{15}$

\begin{tabular}{|l|l|l|}
\hline \multicolumn{1}{|c|}{ Teknik } & \multicolumn{1}{|c|}{ Bentuk Instrumen } & \multicolumn{1}{c|}{ Tujuan } \\
\hline Tes Tulis, Non Tes, & Pilihan Ganda, Uaraian, & Memahami kemampuan \\
intrumen asesmen aspek & Quiz berbasis teknologi & pemhaman pengetahuan \\
pengetahuan berbasisi & & peserta didik dalam proses \\
teknologi & & belajar sebagai pengukuran \\
& & hasil dan perbaikan proses \\
& & \\
\hline
\end{tabular}

Sesuai dengan tabel di atas lebih lanjut untuk membuat bagaimana pengembangan teknik intrumen asesmen aspek pengetahuan melalui teknologi dan dengan perkembangan teknologi dapat membantu dunia pendidikan dalam pengembangan alat penilaian siswa termasuk pada aspek pengetahuan. Seperti pada beberpa aplikasi berbentuk tes, terdapat beragam jenis perangkat teknologi dan layanan aplikasi yang menyediakan berbagai aktivitas baik itu intrumen maupun penilaian. Beberapa layanan tersebut berbentuk ExamView atau Learning Management System (LMS) yang menyediakan tempat untuk menyimpan bank soal dan butir soal, serta administrasi dan pengiriman hasil penilaian. Beragam jenis tersedia pada aplikasi LMS ini, seperti: pilihan ganda, Quiz, esai, menyesuaikan benar salah dan lain-lain. ${ }^{16}$

Teknik tes tulis dalam instrumen asesmen aspek pengetahuan berbasis teknologi dapat kita lihat dalam cara berikut: contoh Soal (Quiz) pada aspek pengetahuan. Beberapa sarana dipenuhi sebagai berikut: ${ }^{17}$

1. Pertama kita harus memiliki Softwaree Exam view 6.2, guna langkah pembuatan Soal/Quiiz/ujian

2. Kemudian Acount sebagai lecturer di moodle.ub.ac.id

3. Softtware MoodleXMLBuielder, kemudian transformasi ke blackboard 6.0-7.0 ke XML

4. Software Secure Exam Browsing "SEB Soal/Quiz V.1.1, yakni browserr yang digun=akan pada Soal/Quiz pada moodle.ub.ac.id

Langkah yang harus didahulukan dengan membuat soal/Quiz dengan software Examview 6.2, alat bantu yang diperlukan: Software Examview 6.2, dalam membuat soal/quiz dan ujian. Langkah-langkahnya.

\footnotetext{
${ }^{15}$ Supratiknya, Penilaian Hasil Belajar dengan Teknik Nontes (Yogyakarta: Universitas Sanata Darma, 2012). Hal. 11-12

${ }^{16}$ Siti Mutmainah, Pemanfaatan TIK Dalam Penilaian (Jakarta: Kemendikbud, 2018). Hal. 19

${ }^{17}$ Heru Nurwarsito, Asesment:Model Aspek Pengetahuan Soal di Moodle (Surabaya: Kemendikbud, 2012). Hal. 2
} 
1. Mencari dan pilih software bisa search Google "Examview 6.2.1 install" atau coba link berikut

2. Download atau instal kemudian dijalankan

3. Setelah selesai terdonwload/terinstal Exmview, membuka pada dokumen baru, dan klik file-new Tes-Isi Test Title/kategoi quiz/soal "Bab 14-Multicore"

Bab 14-Multicore

4. Jika ingin membentuk Soal yang baru, klik pada New - Question Tipe (semisal Multyple Choise) - Ok

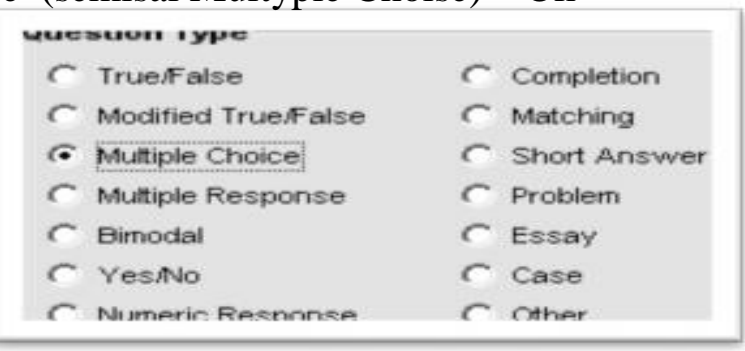

5. kemudian ubah pembahasan/pertanya'an dibagian atas, dan pada alternative jawaban di kotak kemudian dengan menandai (klik) pada jawaban yang benar dan silahkan untuk dimasukkan.

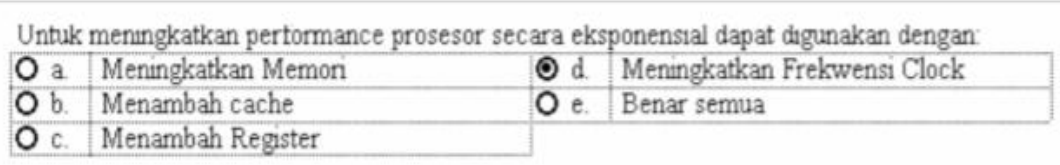

6. jika jawaban yang alternative diinginkan lebih dari pada 4 ppilihan, maka klik chois-5 (untuk 5 pilihan).

Untuk meningkatkan performance prosesor secara eksponensial dapat digunakan dengan

O a. Meningkatkan Memon

O c. Menambah Register

$\mathrm{O}$ b. Menambah cache

O d. Meningkatkan Frekwensi Clock

7. Setelah itu anda dapat mengklik close, kemudian akan terlihat pada dokumen berikut.

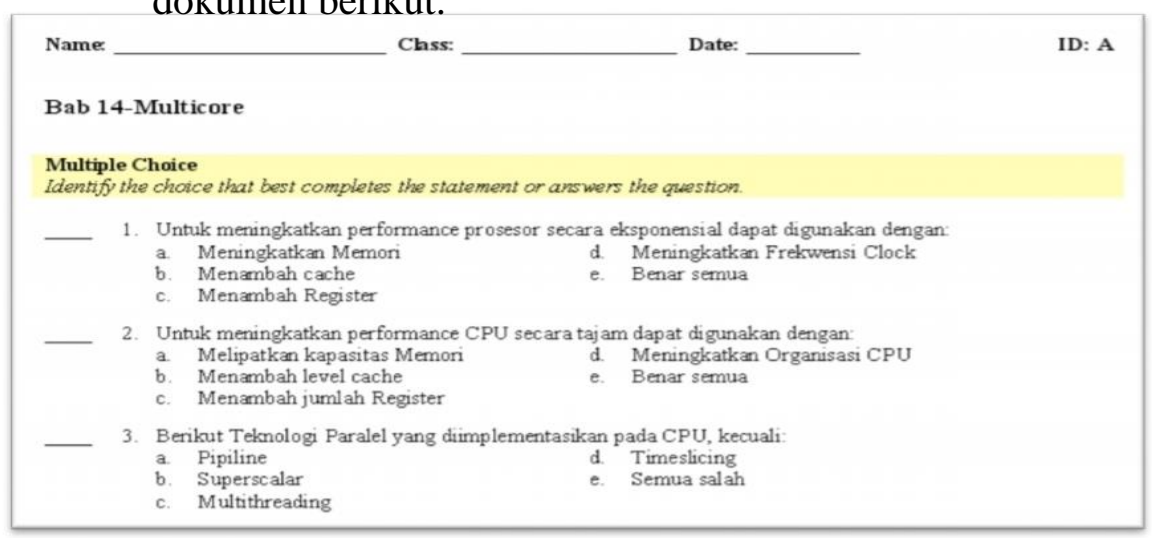


8. Kemudian kita dapat menyimpan dokumen tersebut dengan klik save (menyimpan dokumen) isikan "Bab 14-Multicore.tst".

9. Eksport Examview pada Blackboard 6.0-7.0, dan klik file-Exportblackboard 6.0-7.0 kemudian isi "Bab 14-Multcore.zip". pool information diisikan Nama: Multicore. Isi Directtory: Multicore. Klik. OK.

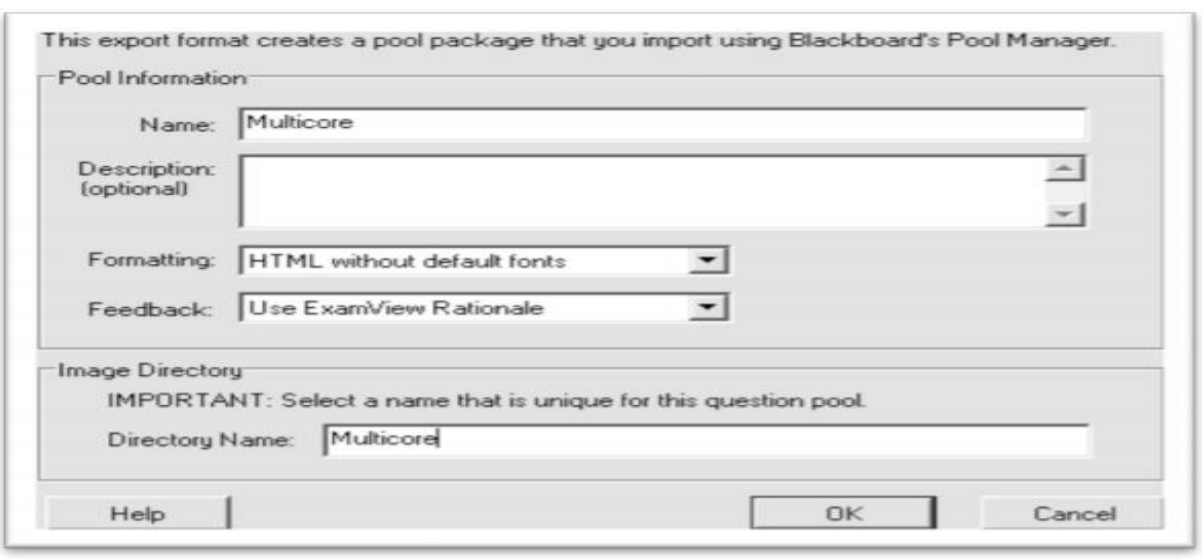

10. Dalam kebutuhan menggabungkan soal/quiz pada semua Test Title/Kategori pada waktu ujian/UTS/UAS hingga dibutuhkan exsport menjadi bank soal, Klik File -export-Examviem Question bank. Soal pada bank ini sangat berguna.

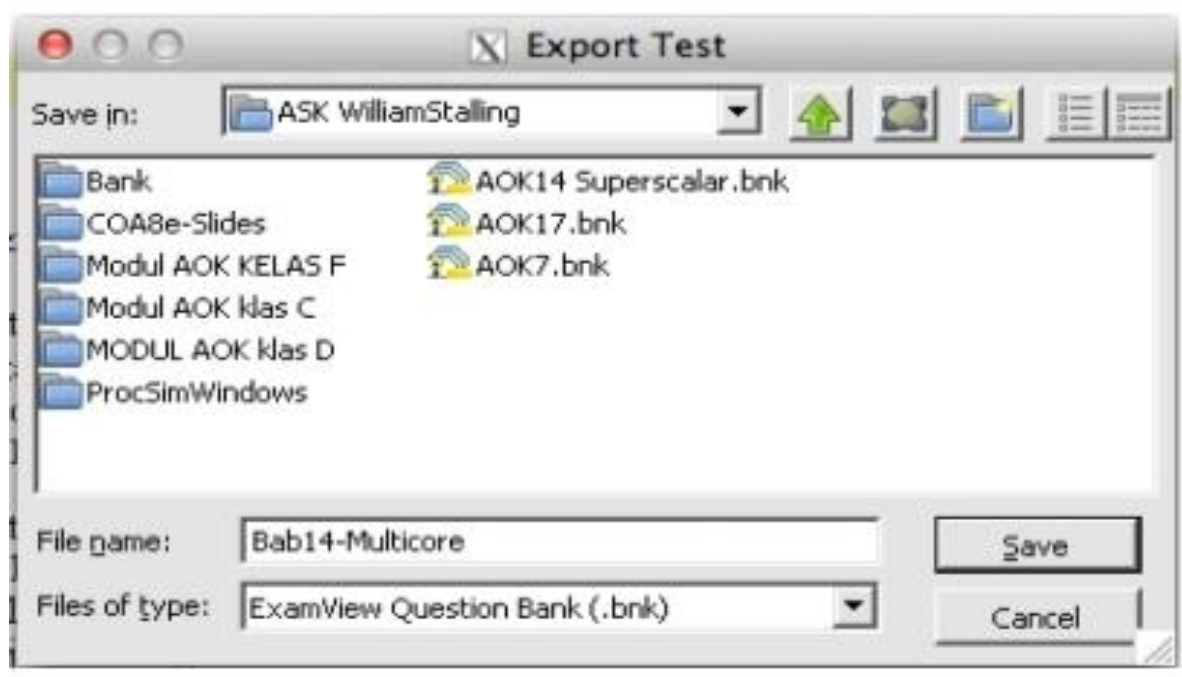

Setelah intrument assmen aspek pengetahuan berbasisi teknologi telah selesai didilakukan, langkah selanjutnya yaitu dengan mengerjakan soal/ Quiz di Moodle atau aplikasi terebut. Adapaun alat/saarana yang dipenuhi: ${ }^{18}$

${ }^{18}$ Heru Nurwarsito, Asesment:Model Aspek Pengetahuan Soal di Moodle (Surabaya: Kemendikbud, 2012), hal. 10 
1. Acount sebagai lecturer pada moodle.ub.ac.id

2. Software Secure Exam Browser "SEB Quiz/soal V.1.1" yakni Brower husus pada soal/quiz di moodle.ub.ac.id

Adapun langkah-langkah selanjutnya

1. Kita dapat mendownload atau menginstal Extract "SEB Soal/Quiz V.1.1"

2. Kemudian menginstal Software "SEB Soal/Quiz V.1.1"

3. Menjalankan Safe Exam Browser Klik "SEB Windows 1.8.2” darii Dekstop.

4. Setelah itu Log in pada moodle.ub.ac.id

5. anda dapat mengklik Soal/Quiz untuk hendak dikerjakan

6. jika waktu Soal/Quiz telah masuk sesuai dengan setting kemudian buka dengan menggunakaqusiofftware Safe Exam Browser, setelah itu Soal/Quiz dapat kita dikerjakanแowed: 1

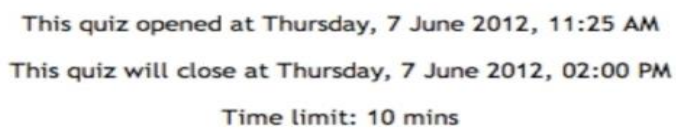

This quiz has been configured so that students may only attempt it using the Safe Exam Browser.

Attempts: 24

Attempt quiz now

7. Kemudian kita dapat mengklik “Attem Quiz Now”. Dikerjakan hingga menjawab semua soal pertanyaan.

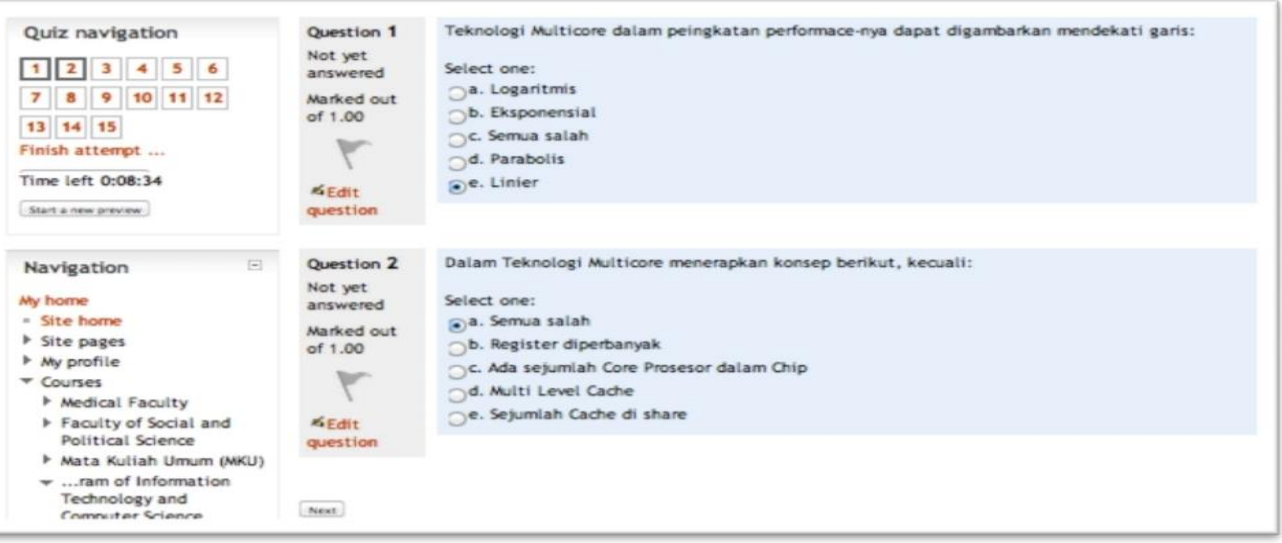


8. Jika ingin mengerjjakan soal/ sebelum klik "Next". Jika ingin kembali kepada soal sebelumnya klik "Nomor soal" pada kiri atas.

9. Apabilah telah menyelesaikan seluruh soal, klik pada "Finish Attemt".

10. Durasi sisa mengerjakan soal/Quiz dapat dilihat "Time Left" dikiri atas, maka waktu Coun-down dan apabila durasi pada pengerjaan soal habis maka Quiz/Soal tidak dapat dilanjutkan. jika durasi segera habis maka harus klik "Finish Attemt" dan/atau"Submit all and Finish" untuk memastikan jawaban bahwa tersimpan keserver moodle.

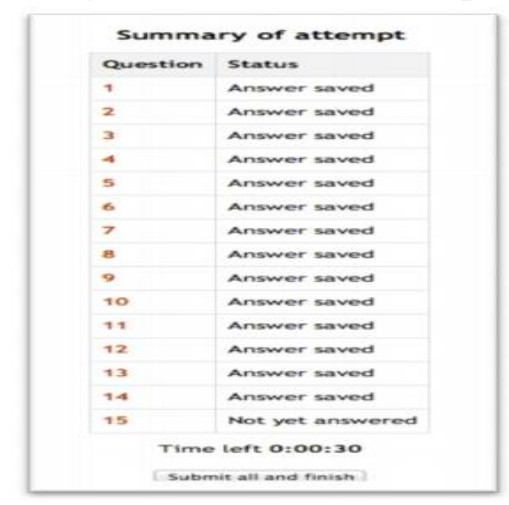

11. Jika ingin merefresh browsing pada waktu koneksi internet lola atau loading lama/macet, tekan F5.

12. Jika ingin keluar dari Safe Exam Browser, tekan pada keyboard F3 plus F4 dan F5 secara bersaman.

13. Apabila Soal/Quiz telah dikerjakan peserta didik, pendidik dapat melihat hasil Quiz/Soal yang telah diberikan, Klik "Quiz/Soal 11 B" Result pada menu sebelah kiri.

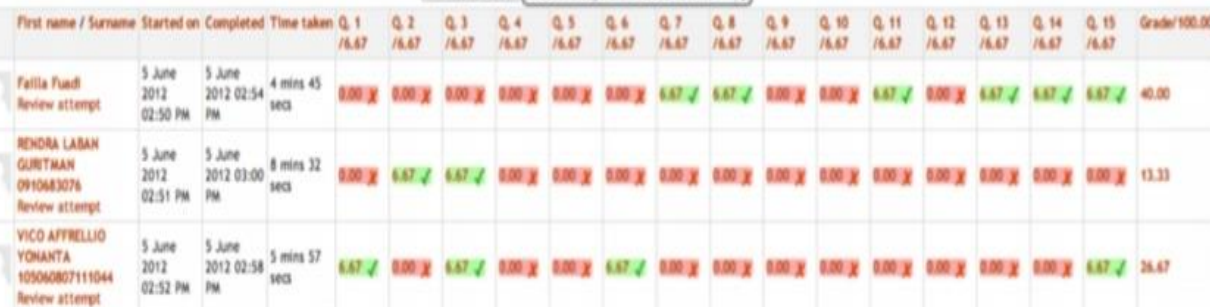

14. Jika ingin mengnstal/download untuk Nilai hasil Quiz/Soal pada File Excel, kita dapat mengklik "Instal file as", aakan muncul "AOKQuiz-11B-Grades.csv" maka file dapat disimpan dan bisa dibuka menggunakan Excel atau dapat juga di upload ke moodle.ub.ac.id, hingga peserta didik dapat melihat hasil test kerjaanya . 
Sedangkan teknik melalui non tes dalam instrumen asesmen aspek pengetahuan berbasis teknologi dapat kita lihat melalui jalur E-fortoolio, Digital Rubric, Alternatif Asesmen digital dan sejenis yang lain. Metode yang digunakan dalam proses asesmen berber nontes yang bisa dikatakan efektif untuk digunakan yaitu salah satunya dengan E-Fortopolio. E-Fortopolio adalah merupakan singkatan dari elektronik fortopolio yaitu media yang merupakan dapat digunakan melalui Browser/web dengancara mengumpulkan bukti elektronik. Yang dimaksud dengan bukti elektronik adalah berupa file elektronik, multimedia, hyperlink, entri blog dan sebagainya. Sehubungan dengan hal tersebut EFotopolio juga sangat dapat membantu pengguna untuk menampilkan ekspresi diri ketika pengguna menggunakanya secara aktif, dengan begitu plat form dapat digunkan secara dinamis. ${ }^{19}$ Cara penggunaan E-Fortopolio tersebut, kita dapat melihat pada laman berikut: https://www.youtube.com/watch? $\mathrm{v}=5 \mathrm{~N} 7 \mathrm{KZFRL7mI}$ https://www.youtube.com/watch?v=2vEldvPK6rc

http://health.usf.edu/publichealth/eta/Rubric_Tutorial/default.htm\#step1

\section{KESIMPULAN}

Asesmen (penilaian) berbasis teknologi ditinjau dari segi pendidikan adalah proses penilian yang dilakukan oleh teanaga pendidik dalam memantau kinerja peserta didik selama proses pembelajaran dengan melibatkan media seperti computer, LCD, Handphone, dan sejenisnya, guna mengoptimalkan pembelajaran yang lebih efesien dan menarik. Pada proses asesmen atau penilaian tidak terlepas dari penilai secara tes dan non tes. Namun pada dasarnya, proses penilian pada rana kognitif atau pengetahuan dapat disuguhkan dengan tes tertulis, lisan, dan penugasan. ketika dibarengi dengan teknologi, begitu banya fitur ataupun aplikasi yang dapat menunjang proses penilaian, seperti exam view, bank soal rumah belajar, e-fortofolio, digital rubric, alternatif asesmen digital.

\section{DAFTAR PUSTAKA}

Agustin, Dian, Nina Kadaritna, dan Lisa Tania. "PENGEMBANGAN INSTRUMEN ASESMEN PENGETAHUAN PADA MATERI TEORI ATOM BOHR DAN MEKANIKA KUANTUM.” Jurnal Pendidikan Dan Pembelajaran Kimia 4, no. 1 (3 Juni 2015): 209-21.

Agustin, Dian, 'Pengembangan Isntrumen Asesmen Pengetahuan Pada Materi Teori Atom Bohr Dan Mekanika Kuantum', Jurnal Pendidikan Dan Pembelajaran Kimia, 4.1. 2015.

\footnotetext{
${ }^{19}$ Pemanfaatan TIK Dalam Penilaian. Hal. 25
} 
Astuti, Widi Puji, Andreas Priyono Budi Prasetyo, dan Enni Suwarsi Rahayu. "PENGEMBANGAN INSTRUMEN ASESMEN AUTENTIK BERBASIS LITERASI SAINS PADA MATERI SISTEM EKSKRESI." Lembaran Ilmu Kependidikan 41, no. 1 (2012). https://journal.unnes.ac.id/nju/index.php/LIK/article/view/2228.

Maruti, Endang Sri, and Naniek Kusumawati. 'Proses Pengembangan Asesmen Alternatif Berupa Penilaian Produk Pada Mata Kuliah Pembelajaran Bahasa Jawa Di Sd', Jurnal Pendidikan Dasar Perkhasa: Jurnal Penelitian Pendidikan Dasar, 2018 <https://doi.org/10.31932/jpdp.v4i2.175>

Heru Nurwarsito. Asesment:Model Aspek Pengetahuan Soal di Moodle. Surabaya: Kemendikbud, 2012.

Hidayat, Tatang, dan Abas Asyafah. "KONSEP DASAR EVALUASI DAN IMPLIKASINYA DALAM EVALUASI PEMBELAJARAN PENDIDIKAN AGAMA ISLAM DI SEKOLAH.” Al-Tadzkiyyah: Jurnal Pendidikan Islam 10, no. 1 (29 Mei 2019): 159-81. https://doi.org/10.24042/atjpi.v10i1.3729.

Nana Syaodih Sukmadhinata. Metode Penelitian Pendidikan. Bandung: PT. Remaja Rosdakarya, 2012.

Raka Joni. Pengukuran dan Penilaian Pendidikan. Malang: Yayasan Pusat Pengkajian Dan Pengembangan Masyarakat, 1984.

Ridwan Abdullah Sani. "Pembelajaran Saintifik untuk Implementasi Kurikulum 2013. Jakarta: Bumi Aksara, 2014.

Setemen, Komang, Luh Joni Erawati, dan I. Ketut Purnamawan. "MODEL PEER ASSESSMENT BERBASIS TEKNOLOGI INFORMASI DAN KOMUNIKASI." Jurnal Pendidikan Teknologi Dan Kejuruan 16, no. 1 (30 Januari 2019): 55-64. https://doi.org/10.23887/jptkundiksha.v16i1.16619.

Siti Mutmainah. Pemanfaatan TIK Dalam Penilaian. Jakarta: Kemendikbud, 2018.

sudaryono. Dasar-Dasar Evaluasi Pembelajaran. Yogyakarta: graha ilmu, 2012.

Sukiman. Pengembangan Sistem Evaluasi”, . Yogyakarta: Insan Madani, 2012.

Supratiknya. Penilaian Hasil Belajar dengan Teknik Nontes. Yogyakarta: Universitas Sanata Darma, 2012.

Suwardi dkk. Panduan Penulisan Skripsi. Yogyakarta: FITK UIN Sunan Kalijaga, 2012.

Tim Penyusun UU RI No 20 Tahun 2003 Tentang Sistem Pendidikan Nasional Bab II Pasal 3. Tujuan Pendidikan Nasional. Jakarta, 2003 